\title{
Political Altruism of Transboundary Water Sharing*
}

\author{
Anik Bhaduri and Edward B. Barbier
}

\begin{abstract}
In the paper, using a political altruism model, we make an attempt to explain why an upstream country might agree to a treaty that recognizes and enforces the water claims of a downstream country. In a natural extension of the standard economic model, it is possible to explain the above phenomena, by allowing for altruism between countries. The altruistic concerns of the countries are dependent on other country's willingness to have a good political relationship. If both the countries maintain favorable political relations with one another, then the upstream country will care about the impacts of its water diversion on the downstream country's welfare. The paper also illustrates the case of water sharing of the Ganges River between India and Bangladesh. The Ganges River, like many other rivers in the world, ignores political boundaries. In Bangladesh, the final downstream country along the Ganges, freshwater availability depends on the share of water diverted by the upstream country, India. For decades, India and Bangladesh failed to resolve the water-sharing issues of the Ganges River. However, in 1996, both India and Bangladesh signed a major new agreement on water sharing (Ganges River Treaty) in an effort to resolve the dispute. Using the political altruism model developed in the paper, we examine why despite needing more water than is available under the treaty, India has adapted to shortages instead of resorting to conflict with Bangladesh.
\end{abstract}

KEYWORDS: transboundary, water sharing, political altruism

*The paper stems from the project "Economic Analysis of Upstream-Downstream Water Allocation in Developing Countries," funded by Stanford University and the Hewlett Foundation. We are grateful to Ken Arrow and Larry Goulder for their support and guidance, as well as participants at a workshop at Stanford for their helpful comments on an earlier version of the paper. We also express our thanks to Thomas Crocker, Rob Godby, Charles Mason and Larry Weatherford for providing valuable and critical comments, and Margie Reis for her assistance. 
Bhaduri and Barbier: Political Altruism of Transboundary Water Sharing

\section{Introduction}

With a growing population and rapidly expanding water demand for development, especially for irrigated agriculture, an upstream country would clearly benefit from continuing to divert more water in transboundary water sharing of a river. From a standard economic perspective, it would be rational for the upstream country not to care about the downstream country and put no weight whatsoever on the net benefit of the latter. However, we know that many upstream countries and many individuals in upstream countries do care about the welfare of downstream countries. This is evident as countries sign far-reaching international agreements on water sharing that seem to be against their own narrowly defined economic self-interests (Wolf et al. 2003).

The issue to be addressed by this paper is the question of why upstream countries agree to forego unilateral water diversion in order to cooperate with downstream countries on water sharing. In agreeing to a treaty, why do the upstream countries not obtain compensation from downstream countries in exchange for lowering upstream diversion levels? The paper proposes that the efficient allocation of water sharing between an upstream and a downstream country may be the result of an alternative motivation: limited pure (non paternalistic) altruism between countries.

In this paper, a pure altruistic model is presented in which the countries care about each other with respect to water sharing. Political relations between the countries are crucial elements influencing the altruistic behavior of the countries.

Here, a model is developed that closely follows the median voter model (Hotelling1929; Black 1948; Downs 1957) to determine the political relationship each country is willing to have with the other country. Given the determined altruistic concerns of the countries, the political altruism model allows determination of the optimal allocation of water sharing between two countries; and demonstrates the conditions under which altruistic cooperation between countries can guarantee an efficient water allocation.

Most of the altruism literature (Chiappori 1988; Bergstorm 1989; Yann 2001) is related to household behavior. This paper makes a unique attempt in defining the altruism of countries on the basis of political democracy, and represents a first analysis to explore transboundary water sharing in the framework of political altruism.

The paper illustrates the case of water sharing of the Ganges River between India and Bangladesh. In Bangladesh, the final downstream country along the Ganges, freshwater availability depends on the share of water diverted by the upstream country, India. For decades, India and Bangladesh failed to resolve the water-sharing issues of the Ganges River. In 1996, both India and Bangladesh signed a major new agreement on water sharing (Ganges River 
Treaty) in an effort to resolve the dispute. Using the political altruism model, we examine why despite needing more water than is available under the treaty, India has adapted to shortages instead of resorting to conflict with Bangladesh.

The paper is structured as follows. The next section outlines the political altruism model of water sharing between the upstream and the downstream country. The key feature of this model is the determination of the expected political relationships in each country, which is necessary for the solution of the model. Section 3 explains how the expected political relationships are derived. Given these political relationships, section 4 shows the conditions that determine the optimum allocation of water shared between the upstream and the downstream country. Section 5 illustrates the Ganges case study, while section 6 discusses the simulation techniques and results. Finally, the conclusion summarizes the main findings and results of the paper.

\section{The Water Sharing Model}

Since 1948, about three hundred international water agreements have been signed and negotiated (Wolfe et. al 2003); and most of them were resolved in negotiations and treaties signed without provision of any side payments, or compensations from downstream countries. It suggests that the upstream countries do care about the welfare of the downstream countries at least to some extent. A natural extension of the standard economic model makes it possible to explain the above phenomena by allowing for political altruism between countries. In this section, we address such issues by formulating a general pure altruistic model. Previous work has indicated that altruism is common among countries, citing unconditional aid from rich to poor countries as one example (Johansson et. al 2002). Here, we also allow for altruism but not through the conventional "aid flow" mechanism.

In the following model, altruism is conditional and entails reciprocity. This paper justifies the reciprocity in altruistic behavior by relating it to a political relationship. If the upstream country expects that the downstream country is willing to have a good political relationship, then the upstream country will be altruistic and will allow more water to flow to the downstream nation. Similarly, if the downstream country expects a good political relationship with the upstream country, it will display altruistic concern and, settle for a lesser amount of water flowing from upstream.

Kolm (2000) has shown that reciprocal behavior among individuals can overcome a number of failures of exchange, thus improving efficiency and economic productivity. Here we show that similar reciprocal altruism between 
countries can also guarantee an efficient allocation of water if the altruistic behavior is reflected in each country's preferences. ${ }^{1}$

We attempt to capture the reciprocal altruism by constructing each country's net benefit in a framework of interdependent utility functions, which depends on their own private benefit and weighted benefit of the other country ${ }^{2}$. Suppose two countries $A$ and $B$ share freshwater of a river. Country $A$ is an upstream country and has an opportunity to unilaterally divert water, while country $B$ is a downstream country where the freshwater availability depends on the water usage of the upstream country. Let $w^{A}$ denote the amount of water diverted by upstream country and $w^{B}$ be the amount of water available to the downstream country. If $W$ is the deterministic flow of river water, then it follows that $w^{A}+w^{B}=W .^{3}$

It is assumed that welfare in both countries is affected by this water allocation decision. Water users in the upstream country will gain if $w^{A}$ increases; similarly, a decline in $w^{B}$ will affect adversely water users in downstream country. Let the benefit functions of each country be denoted as $B^{A}\left(w^{A}\right)$ and $B^{B}\left(w^{B}\right)$. We make the standard assumption that both benefit functions are concave with respect to their arguments. 4

If the upstream country cares only about its own welfare, then it would maximize its benefit function $B^{A}\left(w^{A}\right)$ by choice of water diversion, $w^{A}$, subject only to $W$. The result is the welfare maximizing unilateral diversion of water by the upstream country $A$.

A different outcome might occur, however, if the countries are concerned about the implications of water allocation on the broader political and economic relationships between the two countries. Consider a general model, where the net benefit, $N B^{i}$, of country $i(\mathrm{i}=A, B)$, in the framework of a system of

\footnotetext{
${ }^{1}$ Altruism between countries can exist independently of the political system. In a leviathan or a bureaucratic political economy, for instance, altruism towards other countries exists, and is dictated by one or few people. However in a democratic society altruistic behavior of a country is based on the collective preference of the people reflected in electoral votes, and hence tends to be more stable than determined in an autocratic or bureaucratic system (Goodin 2005 ).

2 Previous studies using interdependent utilities to model altruism include Becker (1974, 1981, ch.8), Bergstrom (1989, 1999), Bruce and Waldman (1991), Dutta and Michel (1998), Hori (1992, 1997), Hori and Kanaya (1989), Horowitz and Wang (2001), Kimball (1987), Kolm (1969), Loury (1981), Ray (1987), and Stark (1995).

${ }^{3}$ We consider water flow to be deterministic to make the model analytically more tractable.

4 A social welfare function includes the welfare of citizens as well as firms. In the model presented, the net benefits of the countries do not represent the total social surplus as the payoffs to firms are not considered. The assumption is made for analytical simplification as inclusion of firm's payoff requires additional parameters and more complexities in simulation procedure. Future work can model the total social surplus in the form of a net benefit as a function of both citizen and firms, and create an attempt to address the wider issue of social welfare.
} 
interdependent utility functions, depends on their own private benefit, $B^{i}$, and a weighted benefit of the other country, $k_{i} N B^{j}(j \neq i)$. The weights $k_{i}$ are the altruistic concerns of country $i$ for $j$, and are based on the degree (better or worse) of the political relationship $\psi^{j}$ that country $i$ is expecting from country $j$. If country $i$ expects that country $j$ is willing to have a good political relationship, then country $i$ will be more altruistic towards country $j$. Though the ruling political party in each country decides the level of foreign relationship, it often echoes by public opinion expressed in the form of political votes given to each party's political agenda. The electorate is assumed to have a notion or preference over policies. Not knowing the true foreign policy of country $j$, country $i$ forms an expectation of the political relationship county $\mathrm{j}$ is willing to support, $E\left(\psi^{i}\right)$, based on the distribution function of desired policies of the electorate in country $j$. The net benefit functions of the countries are assumed to be

$$
\begin{aligned}
& N B^{A}=B^{A}\left(w^{A}\right)+k_{A} N B^{B}\left(w^{A}, w^{B}\right) \\
& N B^{B}=B^{B}\left(w^{B}\right)+k_{B} N B^{A}\left(w^{A}, w^{B}\right)
\end{aligned}
$$

where $k_{A}=E\left(\psi^{B}\right) ; k_{B}=E\left(\psi^{A}\right)$, and $w^{A}+w^{B}=W$

Interdependent net benefit functions introduce an additional layer of complexity. Interdependence engenders indeterminacy. If the net benefit of country $A$ depends on the net benefit of country $B$ which in turn depends on the net benefit of country $A \ldots$...; the net benefits of each country recursively depend on each other. This kind of recursivity arises because agents recognize that the other country's net benefit depends on its own. Equations 2 and 3 can be re-expressed as $N B^{A}=\frac{1}{1-k_{A} k_{B}}\left[B^{A}\left(w^{A}\right)+k_{A} B^{B}\left(w^{B}\right)\right]$

$N B^{B}=\frac{1}{1-k_{B} k_{A}}\left[B^{B}\left(w^{B}\right)+k_{B} B^{A}\left(w^{A}\right)\right]$

As a stability condition, we assume that each country values its own marginal benefit from the consumption of water more than the marginal benefit of the other country for the same amount of water consumption, implying $k_{A} k_{B}<1$ in equations 4 and $5 .^{5}$ As the degrees of expected political relations $E\left(\psi^{i}\right)$ are

5 When $k_{A} k_{B}>1$, an awkward consequence occurs, as the net benefits are monotonically decreasing in their arguments. Both countries prefer less water to more and they disagree about the allocation of water because each country wants the other country to take a larger proportion of water. Bergstorm (1989) argues that stability provides an appropriate concept to solve the paradox. When $k_{A} k_{B}>1$, the solution is unstable and should not be considered as valid. But if $k_{A} k_{B}<1$, each country with independent preference would prefer more water than less and the solution will be stable. 
crucial elements influencing the altruistic behavior of the countries $k_{i}$; the next section describes how these crucial expectation parameters can be derived.

\section{Determination of Expected Political Relationships}

The competing political parties of each country may differ in their views on transboundary water, which will influence how each party views the common objective of maximizing the welfare of the citizens. For instance, one party might argue that cooperative efforts between countries in transboundary water sharing can provide benefits that far exceed the gains from maximizing national welfare only. A rival party, however, could hold the contradictory view and emphasize maximizing only its own country's welfare. The difference in political opinion would yield an optimal transboundary water sharing policy through the electoral competition process that differs from that devised by a single social planner. Here, our objective is to explore how such a transboundary water policy consistent with the collective choice of the people in the face of competing electoral parties might arise. A key requirement is that this political consensus over the collective choice of an optimal transboundary water policy is achieved through a democratic voting system. A common method of characterizing such electoral behavior in social choice theory is the median voter model ${ }^{6}$, which has been applied extensively to problems of conflict resolution (Joan et al. 1999; Reynal 2001; Colomer 2002). In such applications of the median voter model, in the event of a disagreement, each rival party submits a policy offer and the median voter chooses one party whose policy stands closest to the voter's preference (Powell 2000). A similar application of the median voter model to determine the expected political relationship seems appropriate in the context of our model of water sharing between countries.

In the standard median voter model, agents (voters and parties) make decisions in one dimension, i.e. over a single political issue that is the source of conflict among the competing parties. However, in most of the countries political parties have different perspectives on a range of foreign and domestic policies. Thus, one way that our model differs from the usual median voter model is that we assume that the political parties make decisions in more than one dimension, i.e. over a complete "set" or "agenda" of policies. However, the median voter model does not apply easily to multi-dimensional voting models. Plott(1969) suggests that in two-dimensional cases, a median voter exists only in cases where voter tastes are very symmetrically distributed. We apply the median voter model

\footnotetext{
6 The median voter rule was formulated by Harold Hotelling as an application of a theorem in economics (Hotelling 1929) and was developed further by Duncan Black (1948) and Anthony Downs (1957).
} 
to the internal political decision process of both countries involved in the transboundary water dispute. In both the upstream and downstream country the electorate acts on its voting preferences, choosing one political agenda by electing one of the two competing parties.

The following model formalizes the above ideas in a simple game theoretic framework.

We consider the internal political process in country $i(i=A, B)$. We assume that in country $i$ there are two political parties, the liberal party $X^{i}$ and the nationalistic party $Y^{i} .{ }^{7}$ The political parties campaign for votes in a political election; foreign policy, economic policy, and other non-economic domestic policies are the key electoral issues. ${ }^{8}$ Each political party $(k=X, Y)$ offers two kinds of policies: a set of $\psi_{k}^{i}$ domestic economic policy and foreign policies with country $j(j \neq i)$; and, a set of $\phi_{k}^{i}$ other domestic policies unrelated to the foreign and economic policies. We assume that the foreign policy of a country proposed by each party is associated with its proposed domestic economic policy. ${ }^{9}$

The offers $\psi_{X}^{i}$ and $\psi_{Y}^{i}$ can be expressed in terms of an index of the political parties' degree of hostility to country $j$, with a value for $\psi_{k}^{i}$ close to zero implying a very "hostile" relationship with the other country $j$ and very "restrictive" economy while a value of $\psi^{i}$ close to one implying a very "friendly" relationship and very "liberalized" economy, then $\psi_{X}^{i}$ and $\psi_{Y}^{i}$ can be expressed as $0<\psi_{Y}^{i}<\psi_{X}^{i}<1$. Similarly, $\phi_{k}^{i}$ can be expressed as an index of political parties concern over non-economic domestic policies, with a value close to one implying high importance of non economic domestic policies while a value of $\phi^{i}$ close to

\footnotetext{
${ }^{7}$ Liberal refers to a party preferring more liberalized trade policies and good political relations. Nationalistic refers to a party that promotes more restrictive trade policies and is not as concerned with foreign political relations.

${ }^{8}$ The political parties are assumed in the model to be myopic about the electorate's preferred political relationship. They are concerned only about making political "offers" that will help them win votes in the next election only.

9 In the model, the degree to which domestic economic policy is associated with foreign policy is a theoretical construct. Essentially, we are assuming that the upstream and downstream countries are both small open economies, and thus the association of domestic economic policy with foreign policy would naturally follow. For example, this association could be represented in terms of an index of the political parties' degree of hostility to economic relations with a foreign country, or indeed to "globalization" generally, and it could be measured practically by openness to trade, e.g. (Exports+Imports)/GDP. But we have ignored suggesting such an explicit measure as openness to trade, because such a measure can also be influenced by factors other than the electorate's altruism towards a foreign country.
} 
zero implying low importance of such domestic policies. The restriction on $\phi^{i}$ can be expressed as $0<\phi_{X}^{i}<\phi_{Y}^{i}<1 .{ }^{10}$

Before the election, the parties, $X^{i}$ and $Y^{i}$ of country $i$ announce their political agenda if they come into power. The objective function of the political parties is to win an election by choosing an equilibrium set of policies given the voter's preference of policies. The voter's preference over the political relationship with the other country and the desired non economic domestic policies are represented by $Z_{1}$ and $Z_{2}$ respectively. We assume that $Z_{1}^{i}$ and $Z_{2}^{i}$ are uncorrelated.

In the median voter model, the chance of winning an election of a political party is influenced by the decision rule of the median voter. The median voter is the representative deciding voter in a compulsory voting procedure, and it chooses the political agenda by voting for one of the two political parties. The median voter's preference of policies depends on the distribution function of voter's preference of policies.

We assume that the voter's preferred policy, $Z_{l}(l=1,2)$, is normally and independently distributed with mean $m_{l}$ and variance $\sigma_{l}^{2}$. The political parties have no knowledge of $Z_{l}$, but they believe that $Z_{l}$ is randomly distributed according to cumulative distribution $f\left(Z_{l}\right)$ with associated probability density function $f\left(Z_{l}\right)$ where $\frac{\partial F(Z)}{\partial Z}=f(Z)$. As the political party's action and objective of winning an election are based on the belief of the voter's distribution function, the model is probabilistic in nature. In such a typical probabilistic model, the political parties do not directly observe the idiosyncratic pattern of voter's preference. The variance of the distribution function provides a degree of information or knowledge about such uncertainty of voter's preferred policy in a given election.

Using the parity concept, we determine the median voter's decision criteria, which are as follows:

Political party $X$ is chosen if $Z_{1}-\psi_{Y}>\psi_{X}-Z_{1}$, or if $Z_{1}>\frac{\psi_{X}+\psi_{Y}}{2}=\hat{\psi} .{ }^{11}$

Conversely, political party $Y$ is chosen if $Z_{2}-\phi_{X}>\phi_{Y}-Z_{2}$ or if $Z_{2}>\frac{\phi_{X}+\phi_{Y}}{2}=\hat{\phi}$.

\footnotetext{
${ }^{10} \phi$ could also be considered a platform inclination or disposition as opposed to a specific policy.

${ }^{11}$ Decision Rule: Political party $\mathrm{X}$ is preferred if the absolute distance between voter's preferred and the offered policy is less than the distance between the preference and political part Y's offered policy. This is true if $\psi_{X}>\psi_{Y}$, and $\psi_{X}>Z_{1}, \psi_{Y}<Z_{1}$ or $\psi_{Y}<\psi_{X}<Z_{1}$.
} 
The direct chance of winning the election (with a clear electoral mandate) for the political parties $X$ and $Y$ will be $P\left(Z_{1}>\hat{\psi}, Z_{2}<\hat{\phi}\right)$ and $P\left(Z_{2}>\hat{\phi}, Z_{1}<\hat{\psi}\right.$ ) respectively. ${ }^{12}$

However, some times the electorate's mandate is not reflected in the results of an election. Such a situation may arise if the electorate prefers a liberalized economy with a friendly foreign policy $\left(Z_{1}>\hat{\psi}\right)$ and simultaneously attaches high importance to the non-economic domestic policy $\left(Z_{2}>\hat{\phi}\right)$. The situation may also arise if the electorate chooses a restrictive economy with a hostile foreign policy $\left(Z_{1}<\hat{\psi}\right)$ and simultaneously gives low importance to the other non-economic domestic policy $\left(Z_{2}<\hat{\phi}\right)$. Such outcomes occur because the competing parties have political agendas of more than one dimension. If the electorate's preference over the multi-dimensional policy offer is structured in such a way, then it may elect either of the political parties. In such a situation, we have ${ }^{13}$

$$
P\left(Z_{1}>\hat{\psi}, Z_{2}>\hat{\phi}\right)=P\left(Z_{1}<\hat{\psi}, Z_{2}<\hat{\phi} \quad\right) .
$$

Given equation (6), the probability of each political party wining the election is derived as follows

$P\left(\psi_{X}\right.$ chosen $)=$ Probability political party $X$ wins

$$
\begin{aligned}
& =P\left(Z_{1}>\hat{\psi}, Z_{2}<\hat{\phi}\right)+\frac{1}{2} P\left(Z_{1}>\hat{\psi}, Z_{2}>\hat{\phi}\right)+\frac{1}{2} P\left(Z_{1}<\hat{\psi}, Z_{2}<\hat{\phi}\right) \\
& =P\left(Z_{1}>\hat{\psi}, Z_{2}<\hat{\phi}\right)+P\left(Z_{1}>\hat{\psi}, Z_{2}>\hat{\phi}\right) \\
& =P\left(Z_{1}>\hat{\psi}\right) P\left(Z_{2}<\hat{\phi}\right)+P\left(Z_{1}>\hat{\psi}\right) P\left(Z_{2}>\hat{\phi}\right) \\
& =(1-F(\hat{\psi}))[F(\hat{\phi})+(1-F(\hat{\phi})] \\
& =(1-F(\hat{\psi})) .
\end{aligned}
$$

Note that the result shown in the second step derives from equation (6), whereas the outcome shown in the third step arises because $Z_{1}$ and $Z_{2}$ are independent.

Similarly, $P\left(\psi_{Y}\right.$ chosen $)=$ Probability political party $\mathrm{Y}$ wins

$$
\begin{aligned}
& =P\left(Z_{2}>\hat{\phi}, Z_{1}<\hat{\psi} \quad\right)+\frac{1}{2} P\left(Z_{2}>\hat{\phi}, Z_{1}>\hat{\psi}\right)+\frac{1}{2} P\left(Z_{2}<\hat{\phi}, Z_{1}<\hat{\psi} \quad\right) \\
& =(1-F(\hat{\phi})) .
\end{aligned}
$$

\footnotetext{
${ }^{12}$ As the political parties are making decisions in two dimensions, the political parties' chances of winning the election will be different from the case where the agents' decision set is in one dimension. Hence, we restructure the standard median voter model to accommodate the additional dimensionality of the problem.

${ }^{13}$ In such cases, the probability of winning for each political party is $1 / 2$.
} 
As the sum of the probability of a win by political party $X$ and $Y$ is one, we have $(1-F(\hat{\psi}))+(1-F(\hat{\phi}))=1$.

Simplifying the above equation we have $F(\hat{\psi} \quad)=1-F(\hat{\phi})$.

The expected political relation with the other country can be expressed as $E(\psi)=\psi_{Y} \cdot \operatorname{Pr}\left(\psi_{Y}\right.$ chosen $)+\psi_{X} \cdot \operatorname{Pr}\left(\psi_{X}\right.$ chosen $)$

After substituting (7), (8) and (9) in (10) we get

$E(\psi \quad)=\psi_{Y} F(\hat{\psi})+\psi_{X}[1-F(\hat{\psi})] \quad$ where $\quad \hat{\psi}=\frac{\psi_{X}+\psi_{Y}}{2}$

The political party $X$ who wants to have the better relationship with the other country will maximize $E(\psi)$ while the political party $Y$ with the preference of having a less favorable political relationship with the other country will minimize $E(\psi)$.The solution to these choices leads to the following outcomes.

If the pair $\left(\psi_{X}^{*}, \psi_{Y}^{*}\right)$ is to be a Nash equilibrium of the game between the two political parties then $\psi_{Y}^{*}$ must solve $\min _{\psi_{y}} \psi_{Y} F\left(\frac{\psi_{X}^{*}+\psi_{Y}}{2}\right)+\psi_{X}^{*}\left[1-F\left(\frac{\psi_{X}^{*}+\psi_{Y}}{2}\right)\right]$

and $\psi_{X}^{*}$ must solve $\max _{\psi_{x}} \psi_{Y}^{*} F\left(\frac{\psi_{X}+\psi_{Y}^{*}}{2}\right)+\psi_{X}\left[1-F\left(\frac{\psi_{X}+\psi_{Y}^{*}}{2}\right)\right]$

The first order condition of the above optimization problems are respectively

$$
\begin{aligned}
& \left(\psi_{X}^{*}-\psi_{Y}^{*}\right) \cdot \frac{1}{2} f\left(\frac{\psi_{X}^{*}+\psi_{Y}^{*}}{2}\right)=F\left(\frac{\psi_{X}^{*}+\psi_{Y}^{*}}{2}\right) \\
& \left(\psi_{X}^{*}-\psi_{Y}^{*}\right) \cdot \frac{1}{2} f\left(\frac{\psi_{X}^{*}+\psi_{Y}^{*}}{2}\right)=\left[1-F\left(\frac{\psi_{X}^{*}+\psi_{Y}^{*}}{2}\right)\right] .
\end{aligned}
$$

Solving the above two equations yield the following result $F\left(\frac{\psi_{X}^{*}+\psi_{Y}^{*}}{2}\right)=\frac{1}{2}$.

Since the cumulative distribution associated with the probability is that the electorate will choose either offer, evaluated at the average of the two optimal offers, is equal to one half, then this average must also be the median value of the voter's desired political relationship with country $j, Z_{l}{ }^{i}$. That is, the median of the prior distribution on $Z_{1}^{i}$ denoted by $\operatorname{Med}\left(Z_{1}{ }^{i}\right)$, can be expressed as

$$
\operatorname{Med}\left(Z_{1}^{i}\right)=\frac{\psi_{X}^{*}+\psi_{Y}^{*}}{2} \text {. }
$$

Substituting equation (14) in either equation (12) or equation (13) yields 
$\psi_{X}^{*}-\psi_{Y}^{*}=\frac{1}{f\left(\frac{\psi_{X}^{*}+\psi_{Y}^{*}}{2}\right)}$

The above equation suggests that at equilibrium the gap between the political parties' offers must equal the reciprocal of the value of the density function at the median of the voter's preferred political relationship with country $j^{14}$

As the electorate's preferred political relationship with country $j, Z_{l}$, is normally distributed with mean $m$ and variance $\sigma_{\mathrm{i}}^{2}$ and is symmetric around its mean, the median of the distribution equals the mean of the distribution, $m$. So equation (15) becomes

$\operatorname{Med}\left(Z_{1}\right)=\frac{\psi_{X}^{*}+\psi_{Y}^{*}}{2}=m^{i}$

and equation (16) can be written as

$\psi_{X}^{*}-\psi_{Y}^{*}=\frac{1}{f(m)}=\sigma \sqrt{2 \pi}$.

Solving equations (17) and (18) yield the following equilibrium values of $\psi_{X}^{*}$ and $\psi_{Y}^{*}$

$\psi_{X}^{*}=m+\sigma \sqrt{\frac{\pi}{2}}$

$\psi_{Y}^{*}=m-\sigma \sqrt{\frac{\pi}{2}}$

Substituting equations (14), (19) and (20) in (12) yields the equilibrium value of country $i$ 's expected political relationship with country $j$

$E\left(\psi^{i}\right)=\frac{\psi^{i^{*}}+\psi_{Y}^{i^{*}}}{2}=m^{i}$.

The expected political relationship is free of the political parties' uncertainty about the voter's preferred political relationship with country $j$, even though each party's optimal offer was made by taking into account that the voters' actual preference is not known. If there is little uncertainty about the electorate's preferences, i.e. $\sigma_{i} \rightarrow 0$ in (19) and (20), then neither party can afford to make an offer far from the median because the electorate will prefer the party whose offer of a political relationship with country $j$ is closest to $m^{i}$.

\footnotetext{
${ }^{14}$ The density at the median in a symmetric distribution will be higher if the political parties are certain about the electorate's preferred foreign political relationship at the median. In such a case, the difference between the political parties' offer will approach zero if the density at the median of the distribution becomes larger.
} 
Changes in fundamental assumptions and parameters of the political economy model with voting, however, could alter the degree of a country's altruism toward the other country. It is worth discussing some of these implications in further detail.

In a democratic country, as assumed in our model, voters in the form of electorates have the power to exhibit their preferences for altruism through consensus choice. As political parties choose an appropriate policy to win an election, given the electorates preference of policies, the political party's offered policy also reflect voters' altruism. However, Arrow's theorem (Arrow 1951) suggests that there are limits on democracy delivering an efficient Pareto optimal collective choice. With one-dimensional policies, policies tend to be somewhat centrist but with multidimensional policies, a policy becomes much less stable.

In other kinds of political governance systems, for instance oligarchies, autocracies, or dictatorships, altruism also exists but is dictated by a few people. Policy decisions under such political systems might take lesser time to implement, yet yield benefits to a narrower segment of society to the detriment of society overall. Moreover the policy could be less stable given the possibility of a sudden regime change compared to the one decided by a collective choice in a democratic system. In a democracy, even though it may take more time for the political parties to make the median offer of a political relationship and a longer time to reach an agreement, a policy decision once taken could potentially be more stable and sustaining in the long run. For instance, Dutta et. al (2007) and Goodin (2005) have shown that electorate preferred policy choices are significantly more stable over time in democracies.

A country's altruism can also be influenced by the distribution of the electorate's preference. Here, we have assumed that the distribution function of the electorate is symmetric, as the median voter exists only in cases where voter tastes are symmetrically distributed (Plott 1967; Colomer 2002). An asymmetric distribution of the voter's preference with a two dimension policy space could be a more realistic assumption. Asymmetric distribution can generate an equilibrium with mixed strategies (Plott 1967), and alter the political relationship offered by the country. However, for analytical simplicity we have followed the convention in most public choice models of majority decision making and assumed a symmetric distribution.

However, increases in the dispersion of the distribution of voter preferences (e.g., increased "radicalism") will have no effect on altruism unless increased dispersion also affects the median of the distribution of voter's ideal points. This implies that the median voter policies tend to be relatively more stable than would have been the case if average (mean) rather than median voter opinions determine policy (McKelvey 1976). The properties of the median imply 
that public policies will be relatively stable (robust) through time as voters are subject to political shocks.

In the model, we have assumed that the political parties have symmetric information of the electorate's preference towards a political relationship with the other country. If the information about the voter's preferred policy is asymmetric, then the political party that has the greater power to estimate the true variance of the distribution function will have a higher chance to offer a political relationship closer to that of the median voter's and win an election.

Finally, imperfect information about the voter's preferred policy may lead to higher uncertainty in the election results. The uncertainty would decrease over time with a continued democratic governance system, and the political parties would offer a policy close to the electorate's mean preferred policy.

\section{Solution of the Water Sharing Model}

Based on the knowledge of the distribution function of the electorate's desired policies , $\left(m^{i}\right)$, in country $j(j=A, B)$, each country $i(j \neq i)$ forms an expectation about the degree of the political relationship $E\left(\psi^{j}\right)$ offered by the other country $j .{ }^{15}$ Depending on the degree of the expected political relationship, countries offer different levels of altruism $\left(k^{i}=m^{j}\right)$. Finally, given the determined altruistic concerns of the countries, the political altruism model determines the optimal allocation of water sharing between two countries.

Figure 1 illustrates the optimal allocation of water determined by the political altruism factors. The vertical axes (left and right) measure the marginal benefits of country $A$ and $B$ respectively. The water consumption of country $A$ is measured from the left horizontal axes while from the right corner of the horizontal axis we measure the water consumption of country $B$. If country $A$ unilaterally diverts water, then optimal allocation of water $\left(w^{A *}\right)$ will be determined when the marginal benefit is equal to zero. With altruism, country $A$ will divert more water to country $B$ than without altruism.

Substituting $k^{i}=E\left(\psi^{j}\right)=m^{j}$ in equation 4, optimal water diversion with altruism can be determined by maximizing the following net benefit function of country $A$ :

$$
N B^{A}=\frac{1}{1-m^{A} m^{B}}\left[B^{A}\left(w^{A}\right)+m^{B} B^{B}\left(w^{B}\right)\right]
$$

subject to the water allocation constraint. $w^{A}+w^{B}=W$.

The first order condition of the above problem can be represented by

\footnotetext{
15 As assumed before, the political parties in both the countries are myopic with respect to the electorate's preferred political relationship, and they believe that the mean of the distribution remains the same over time.
} 
$\frac{\partial B^{A}}{\partial w^{A}}=m^{B} \frac{\partial B^{B}}{\partial w^{A}}$.

The above equation states that the marginal benefit to country $A$ of a change in the amount of water diverted upstream $\left[\frac{\partial B^{A}}{\partial w^{A}}\right]$ must equal the value that country $A$ places on a decrease in the level of water available to country $B$ $\left[m^{B} \frac{\partial B^{B}}{\partial w^{A}}\right]$. Solving the first order condition yields the optimal consumption of water.

The optimal allocation of water chosen by country $A,\left(w_{3}^{*}\right)$ is influenced by the political economy factor $m^{B}$ (see Figure 1). If the electorate in country $B$ prefers to have a better relationship with country $A$, then the latter country will reciprocate by showing a greater degree of altruism and diverting more water in the downstream country. Conversely, country $B$ 's claim for water will be lower with altruism. In the absence of altruistic concerns, country $B$ would claim an amount of water $w^{B} *$ which is greater than the case where optimal water demand is determined with altruism $w_{1}^{*}$ (see Figure 1).

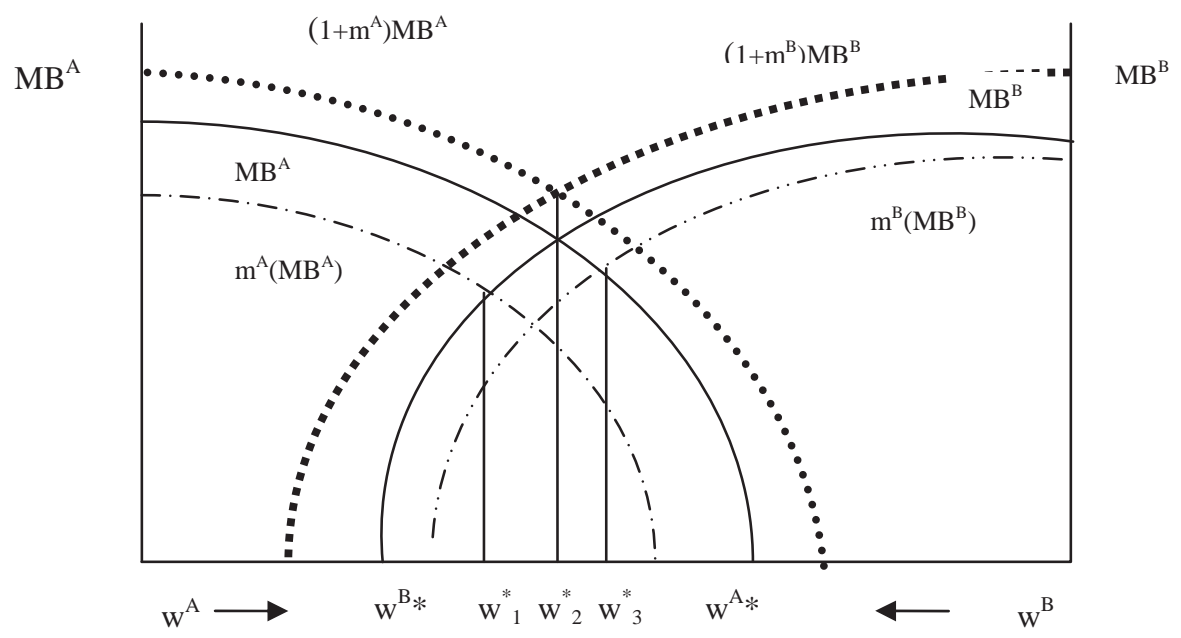

Figure 1: Allocation of water as determined by political altruism

Country $B$ 's net benefit with altruism will be maximized with an optimal water demand $w^{*}{ }_{1}$ when the marginal benefit of a change in the amount of water diverted downstream, $M B^{B}$, is equal to the weighted marginal benefit of country $A, m^{A}\left(M B^{A}\right)$ (see Figure 1). If country $A$ maintains a favorable political relationship with country $B$, the latter country will demand lesser water from 
country $A$ because of altruism. Countries $A$ and $B$ desire the same water allocation if $m^{A} m^{B}=1$, but this restrictive condition on $m^{A}$ and $m^{B}$ will yield either extreme happiness $(N B=\infty)$ or extreme unhappiness $(N B=-\infty)$ for both the countries (see Figure 1). Perhaps the conclusion should be that 'true lovers are very happy (or very unhappy)'.

According to the Coase Theorem (Coase 1960), the countries will choose a water sharing allocation on the Pareto efficiency frontier - a water allocation which is Pareto efficient. Choosing an allocation on the Pareto efficiency frontier is equivalent to maximizing the joint net benefits. The joint net benefits of the countries without altruism are represented by $V=B^{A}\left(w^{A}\right)+B^{B}\left(w^{B}\right)$.

The efficient allocation of $W$ is determined by maximizing the above function subject to $w^{A}+w^{B}=W$, where the first order condition of the above problem can be stated as $\frac{\partial B^{A}}{\partial w^{A}}=\frac{\partial B^{B}}{\partial w^{A}}$.

The first order condition of the above problem implies that if each country does not care about the other country, then an efficient allocation of water $w^{*}{ }_{2}$ will take place when the aggregate of marginal benefits of countries from an increase in water consumption is equal to zero (see Figure 1). Such a water allocation will guarantee an efficient allocation of water between the upstream and the downstream country.

If both the countries care about each other, then a cooperative outcome can be determined by maximizing the joint net benefit of the countries

$V=\frac{1}{1-m^{A} m^{B}}\left[\left(1+m^{A}\right) B^{A}\left(w^{A}\right)+\left(1+m^{B}\right) B^{B}\left(w^{B}\right)\right]$

subject to the water supply constraint, $w^{A}+w^{B}=W$, and the first order condition

of the above problem can be stated as $\left(1+m^{A}\right) \frac{\partial B^{A}}{\partial w^{A}}=\left(1+m^{B}\right) \frac{\partial B^{B}}{\partial w^{A}}$

The first order condition of the above problem implies that a cooperative outcome of allocation of water is guaranteed when the aggregate of the weighted marginal benefits of the countries from an increase in water consumption is equal to zero, with weights $m^{A}$ and $m^{B}$ being the altruistic factors. The water sharing allocation $w_{2}^{*}$ will be Pareto efficient if the countries are equally altruistic about the other countries (see Figure 1). Hence, if $m^{A}=m^{B}$, altruistic cooperation will guarantee an efficient water allocation for values of $m^{A}$ and $m^{B}$ satisfying the restriction $m^{A} m^{B}<1$.

Water sharing between countries based on political altruism has important policy implications. The results of the model indicate that if the countries are equally altruistic about the other country, a water allocation can be achieved which would approximate the water allocation determined by the social planner. The social planner problem of joint welfare maximization of the countries 
chooses an allocation of water which is Pareto efficient. Given the sovereignty issues, it is difficult for a benevolent social planner to exist, but countries can agree on a similar allocation of water, if they share equally altruistic concerns about each other. Ironically, this might be the case even if the two countries display low, but equal, altruism. For example, the Indus River Treaty is one such instance, where a water sharing treaty was signed between the two countries (India and Pakistan) with equally hostile (low altruism) relationship (Alam 1998). However, if one country acted more out of self-interest than the other country, the outcome might not have been efficient and sustaining in the long run as achieved with the Indus Water Treaty.

\section{Ganges River Case Study}

The Ganges River, like many other rivers in the world, ignores political boundaries while flowing. In Bangladesh, the final downstream country along the Ganges, freshwater availability depends on the share of water diverted by India, the next country upstream (see Appendix Figure A.1). For many decades, India and Bangladesh failed to resolve issues of sharing the water of the Ganges River. In 1996, India, by signing a treaty with Bangladesh (The Ganges Treaty) changed its water sharing policy with Bangladesh and cut its water allocation for agriculture and other uses to adjust to the new international relationship with Bangladesh $^{16}$. A key factor leading to the successful negotiation of the Ganges River Treaty was that the political electorates in both India and Bangladesh in the early 1990s appeared to favor better relations with their neighbor, and as a result, the governing political parties of the time reflected this point of view.

The following analysis explains ex post the paradox as to why the Ganges Treaty was acceptable to both the countries, even though India would benefit more from unilateral water diversion in the upstream. Overall, the following analysis not only provides an answer to why the Ganges Treaty was signed, but also investigates the conditions, which may cause a breakdown of the Treaty.

Following the political altruism modeling approach, and considering India and Bangladesh as country $A$ and $B$ respectively, the net benefit function of India (A) can be represented as in equation 22 . We measure the probabilities of the countries in accepting the Ganges Treaty that they might have accepted based on

\footnotetext{
16 The Ganges River Treaty has influenced the water allocation of both India and Bangladesh. Based on historical data (from 1949-1988) on water flows at Farakka, the treaty apportioned water for both countries at different times and seasons of the year. The Treaty requires India to release water downstream to Bangladesh from Farakka to meet the downstream water flow obligations outlined in the Ganges River Treaty.
} 
the possible gain in net benefits. If the probability of India accepting the Ganges Treaty $p^{A}$ depends on the gains in India's net benefit, then it can be computed as

$$
P^{A}=\frac{E(N B)_{\text {Treaty }}{ }^{A}-N B\left(w^{*^{A}}\right)}{N B\left(w^{*^{A}}\right)}=\left[\frac{E\left(B_{\text {treaty }}{ }^{A}\right)+m^{B} E\left(B_{\text {treaty }}{ }^{B}\right)}{B^{A}\left(w^{*^{A}}\right)+m^{B} B^{B}\left(w^{*^{A}}\right)}-1\right]
$$

where $E(N B)_{\text {Treaty }}{ }^{A}$ is the expected net benefit of India from the Ganges Treaty and $N B\left(w^{*^{A}}\right)$ represents the net benefit of the latter country without any treaty from optimal water consumption $w^{* A}$.

The above equation suggests that the probability of India accepting the Ganges Treaty $p^{A}$ is independent of the extent of the political relationship that the latter country is willing to maintain with Bangladesh $m^{A}$, even though it could affect its own net benefit. Equation 28 suggests that $p^{A}$ is dependent only on the level of the political relationship Bangladesh is willing to maintain with India $m^{B}$. We evaluate the change in the probability of India accepting the Ganges Treaty $p^{A}$ for a change in Bangladesh's political relationship with India $m^{B}$, which can be expressed as

$\frac{\partial p^{A}}{\partial m^{B}}>0$ if $\frac{B^{*_{A}}}{E\left(B^{A}\right)}>\frac{B^{* B}}{E\left(B^{A}\right)}$

Otherwise, $\frac{\partial p^{A}}{\partial m^{B}}<0$.

As India shares water with Bangladesh according to the Ganges Treaty, it experiences risk in forgoing water to Bangladesh. The risk is due to the uncertainty reflected in India's expected private benefit $E\left(B^{A}\right)$. If India diverts water without any treaty, it is guaranteed a certain private benefit $B^{*^{A}}$ as it diverts water maximizing its own net benefit. ${ }^{17}$ The above expression 29 implies that if India is relatively less risk averse than Bangladesh $\frac{B^{*^{A}}}{E\left(B^{A}\right)}>\frac{B^{*^{B}}}{E\left(B^{B}\right)}$, then India's chance of agreeing to the Ganges Treaty would increase with altruism. ${ }^{18}$ Given the stochastic nature of water flow, there are two effects on the country's welfare,

\footnotetext{
$17 \mathrm{I} t$ is worth noting in the case without a Treaty, water division is based on long term average flow of water, $\bar{W}$.

18 A country is risk averse if $E\left(B^{i}\right)<B^{i}$ or $\frac{B^{i}}{E\left(B^{i}\right.}>1$. Also note $B^{*^{A}}$ is sufficiently higher than $B^{* B}$.
} 
which may influence the country's probability of accepting the treaty, which we may call the altruism effect and the endowment effect.

Figure 2 illustrates the probability of India accepting the Ganges Treaty as a function of Bangladesh's political relationship with India. Equation 29 suggests the relation to be concave as $\frac{\partial^{2} p^{A}}{\partial m^{B^{2}}}<0$. The concavity of the relationship between India's probability of accepting the Treaty and its altruism can be explained with altruism and endowment effects. Initially when $m^{B}<m^{*^{B}}$, India keeps more water for itself and its endowment of water will be high.

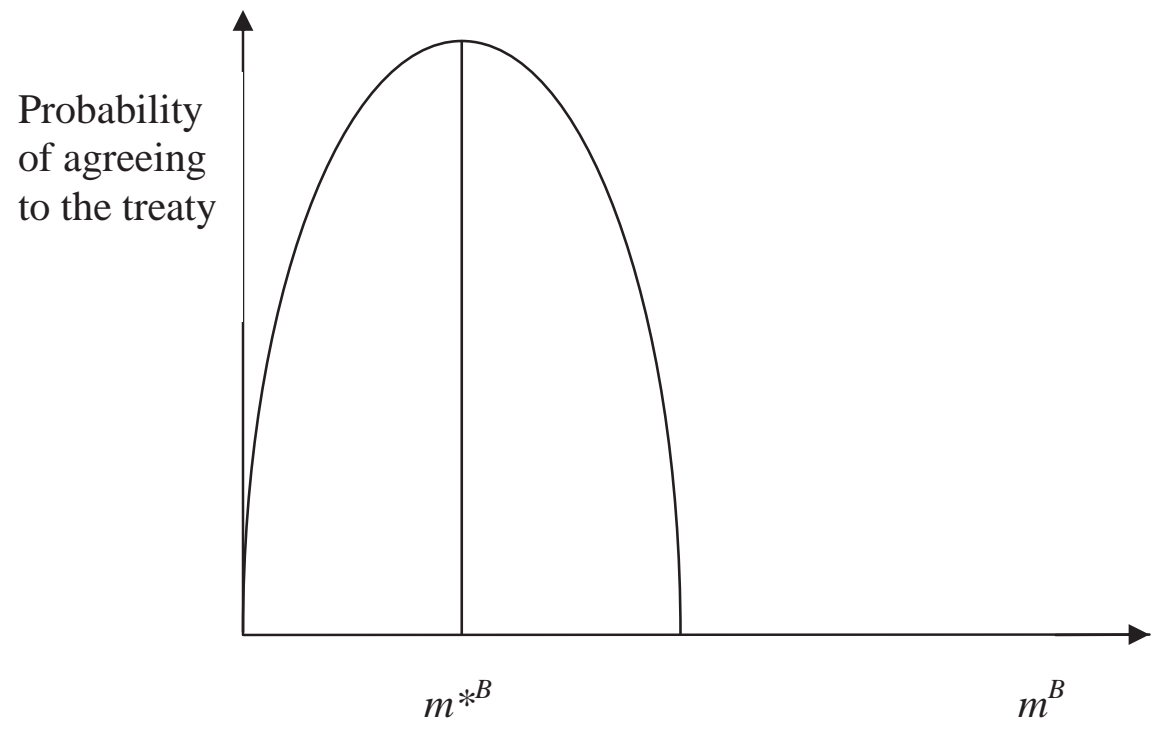

Figure 2: Theoretical illustration of the relationship between India's probability of accepting the Ganges Treaty and its political altruism

Given the high endowment of water, India is less risk averse, therefore altruistic concern will be the main motivating force for India to divert more water downstream. Here, we say the altruism effect will dominate the endowment effect. India's marginal net benefit will be more greatly influenced by an increase in Bangladesh's productivity of water than the loss in its own benefit from decreased domestic water consumption. With higher net benefit, India's probability of accepting the treaty will increase with its altruism. If $m^{B}>m^{*}$, then the endowment effect dominates the altruism effect. If India's altruism concerns were high, then it would divert more water downstream and decrease its own endowment of water. Lower endowment of water will increase India's risk 
aversion due to uncertainty in the flow of water. A further decrease in the share upstream would create a greater loss in India's net benefit as Bangladesh's gain from more water consumption will be less than India's loss from forgoing water. This will induce India to accept the treaty with a lower probability. The altruism level $m^{* B}$ that allows India to attain the maximum probability of accepting the treaty depends on the balance of the altruism and the endowment effects. Note that as $m^{* B}$ approaches its maximum value, India views the downstream benefits as of equal or near importance to that of its own upstream benefits, and the problem is similar to benefit maximization over the whole basin.

\section{Simulation Techniques and Results}

We test the hypothesis implied in the theoretical result using simulation techniques. We have used @ Risk software to simulate employing the Latin Hypercube sampling technique. ${ }^{19}$ Table 1 illustrates the simulation methods and values. It shows the parameters values, distribution function and the method used in computation of each variable and parameters. The key parameters involved in the simulation are India and Bangladesh's level of political relationship with the other country denoted, $m^{A}$ and $m^{B}$. We considered a range of values of each of these parameters on the basis of which we perform the simulation. As each country cares more about itself than the other country, the values of parameter $m^{A}$ and $m^{B}$ are considered to lie between 0 and 1 .

\section{Table 1. Simulation methods and values}

\begin{tabular}{|c|c|c|}
\hline Parameters and Variables & Computation and Values & Explanation \\
\hline $\begin{array}{l}\text { India's political relationship } \\
\text { with Bangladesh, } m^{I}\end{array}$ & {$\left[\begin{array}{lll}0.1 & 0.9\end{array}, 0<m^{A}<1\right.$} & $\begin{array}{l}\text { India cares more about itself } \\
\text { than Bangladesh. }\end{array}$ \\
\hline $\begin{array}{l}\text { Bangladesh's political } \\
\text { relationship with India, } m^{B}\end{array}$ & {$\left[\begin{array}{lll}0.1 & 0.9\end{array}, 0<m^{B}<1\right.$} & $\begin{array}{l}\text { Bangladesh cares more about } \\
\text { itself than India. }\end{array}$ \\
\hline $\begin{array}{l}\text { Bangladesh's political } \\
\text { relationship endogenously } \\
\text { dependent on share of water } \\
\text { diversion }\end{array}$ & $m^{B}=1-\alpha$ & $\begin{array}{l}\text { The functional form is based } \\
\text { on the assumption of a } \\
\text { negative relationship between } \\
\text { Bangladesh's political } \\
\text { relationship and a share of } \\
\text { water diverted by India. The } \\
\text { linear function is assumed for } \\
\text { computational simplicity. }\end{array}$ \\
\hline
\end{tabular}

\footnotetext{
19 The Latin Hypercube technique requires fewer model iterations to approximate the desired variable distribution than the simple Monte Carlo method, and ensures that the entire range of each variable is sampled. In the simulation, more than 10,000 iterations are used.
} 
Bhaduri and Barbier: Political Altruism of Transboundary Water Sharing

\begin{tabular}{|c|c|c|c|c|c|}
\hline \multicolumn{3}{|c|}{ Water flow of the Ganges, $W$} & $\begin{array}{ll}\bar{W}+\varepsilon \quad \varepsilon \text { follows } & \text { RISK } \\
\text { lognormal }(0, \sigma) & \\
\bar{W}=77413(\text { long } & \text { term } \\
\text { average flow of water }) & \\
\sigma=13790 & \end{array}$ & \multicolumn{2}{|c|}{$\begin{array}{l}\text { Derived from existing } \\
\text { empirical data; used best fit } \\
\text { software to derive the } \\
\text { distribution }\end{array}$} \\
\hline \multicolumn{3}{|c|}{$\begin{array}{l}\text { Water consumption of India } \\
\text { under Ganges Treaty, } \\
E\left(w_{\text {Treaty }}\right)\end{array}$} & $\begin{array}{ll}\text { If } W<70000, & w_{\text {Treaty }}{ }^{A} \\
=0.5^{*} W, & \\
\text { otherwise } & \min (\mathrm{W}- \\
35000,40000)) & \end{array}$ & \multicolumn{2}{|c|}{ From Ganges Treaty } \\
\hline \multicolumn{3}{|c|}{$\begin{array}{l}\text { Water consumption of } \\
\text { Bangladesh } \\
\text { under Ganges Treaty, } \\
E\left(w_{\text {Treaty }}{ }^{2}\right)\end{array}$} & $W-E\left(w_{\text {Treaty }}^{A}\right)$ & \multicolumn{2}{|c|}{$\begin{array}{l}\text { Residual flow of water to } \\
\text { downstream }\end{array}$} \\
\hline \multicolumn{3}{|c|}{$\begin{array}{l}\text { Benefit function of India, } \\
E\left(B_{\text {Treaty }}^{A}\right)\end{array}$} & $B_{\text {Treaty }}{ }^{A}=e^{A}\left(E\left(w_{\text {Treaty }}{ }^{A}\right)\right)^{1 / 2}$ & \multicolumn{2}{|c|}{$\begin{array}{l}\text { The form of India's benefit } \\
\text { function is based on the } \\
\text { concavity assumption. The } \\
\text { quadratic benefit function is } \\
\text { assumed for computational } \\
\text { simplicity }\end{array}$} \\
\hline \multicolumn{3}{|c|}{$\begin{array}{l}\text { Technical efficiency of water } \\
\text { usage in India }, e^{A}\end{array}$} & $e^{A} \in\left[\begin{array}{lll}0.40 .6\end{array}\right]$ & \multicolumn{2}{|c|}{$\begin{array}{l}\text { Efficiency of water usage in } \\
\text { India derived from FAO } \\
\text { statistics }\end{array}$} \\
\hline \multicolumn{3}{|c|}{$\begin{array}{l}\text { Benefit function of } \\
\text { Bangladesh, } E\left(B_{\text {Treaty }}{ }^{B}\right)\end{array}$} & $B_{\text {Treaty }}{ }^{B}=e^{B}\left(E\left(w_{\text {Treaty }}{ }^{B}\right)\right)^{1 / 2}$ & \multicolumn{2}{|c|}{$\begin{array}{l}\text { The form of Bangladesh's } \\
\text { benefit function is based on } \\
\text { the concavity assumption. } \\
\text { The quadratic benefit } \\
\text { function is assumed for } \\
\text { computational simplicity }\end{array}$} \\
\hline \multicolumn{3}{|c|}{$\begin{array}{l}\text { Technical efficiency of water } \\
\text { usage in Bangladesh, } e^{B}\end{array}$} & $e^{B} \in\left[\begin{array}{ll}0.3 & 0.5\end{array}\right]$ & \multicolumn{2}{|c|}{$\begin{array}{l}\text { Efficiency of water usage in } \\
\text { India derived from FAO } \\
\text { statistics }\end{array}$} \\
\hline $\begin{array}{l}\text { Expected net } \\
\text { benefit of India } \\
\text { under Ganges } \\
\text { Treaty, } \\
E(N B)_{\text {Treaty }}^{A}\end{array}$ & \multicolumn{4}{|c|}{$E(N B)_{\text {Treaty }}^{A}=\frac{1}{1-m^{A} m^{B}}\left[E\left(B_{\text {Treaty }}^{A}\right)+m^{B} E\left(B_{\text {Treaty }}^{B}\right)\right]$} & \multirow{2}{*}{$\begin{array}{l}\text { The form } \\
\text { of net } \\
\text { benefit } \\
\text { function of } \\
\text { each } \\
\text { country is } \\
\text { derived } \\
\text { from the } \\
\text { political } \\
\text { altruism } \\
\text { model }\end{array}$} \\
\hline $\begin{array}{l}\text { Expected net } \\
\text { benefit of } \\
\text { Bangladesh } \\
\text { under Ganges } \\
\text { Treaty, } \\
E(N B)_{\text {Treaty }}{ }^{\text {B }}\end{array}$ & \multicolumn{4}{|c|}{$E(N B)_{\text {Treaty }}^{B}=\frac{1}{1-m^{A} m^{B}}\left[E\left(B_{\text {Treaty }}^{B}\right)+m^{A} E\left(B_{\text {Treaty }}^{A}\right)\right]$} & \\
\hline \multicolumn{4}{|c|}{\begin{tabular}{l|l} 
Benefit function of & ${ }_{B}^{A}=e^{A}\left(w^{A}\right)^{1 / 2}$ \\
India without & \\
Ganges Treaty, $B^{A}$ &
\end{tabular}} & \multirow{2}{*}{\multicolumn{2}{|c|}{$\begin{array}{l}\text { The form of benefit } \\
\text { function is based on the } \\
\text { concavity assumption. } \\
\text { The quadratic benefit } \\
\text { function is assumed for } \\
\text { computational } \\
\text { simplicity }\end{array}$}} \\
\hline \multicolumn{2}{|c|}{$\begin{array}{l}\text { Benefit function of } \\
\text { Bangladesh- without } \\
\text { Ganges Treaty, } B^{B}\end{array}$} & \multicolumn{2}{|c|}{$B^{B}=e^{B}\left(w^{B}\right)^{1 / 2}$} & & \\
\hline
\end{tabular}

Published by The Berkeley Electronic Press, 2008 
The B.E. Journal of Economic Analysis \& Policy, Vol. 8 [2008], Iss. 1 (Topics), Art. 32

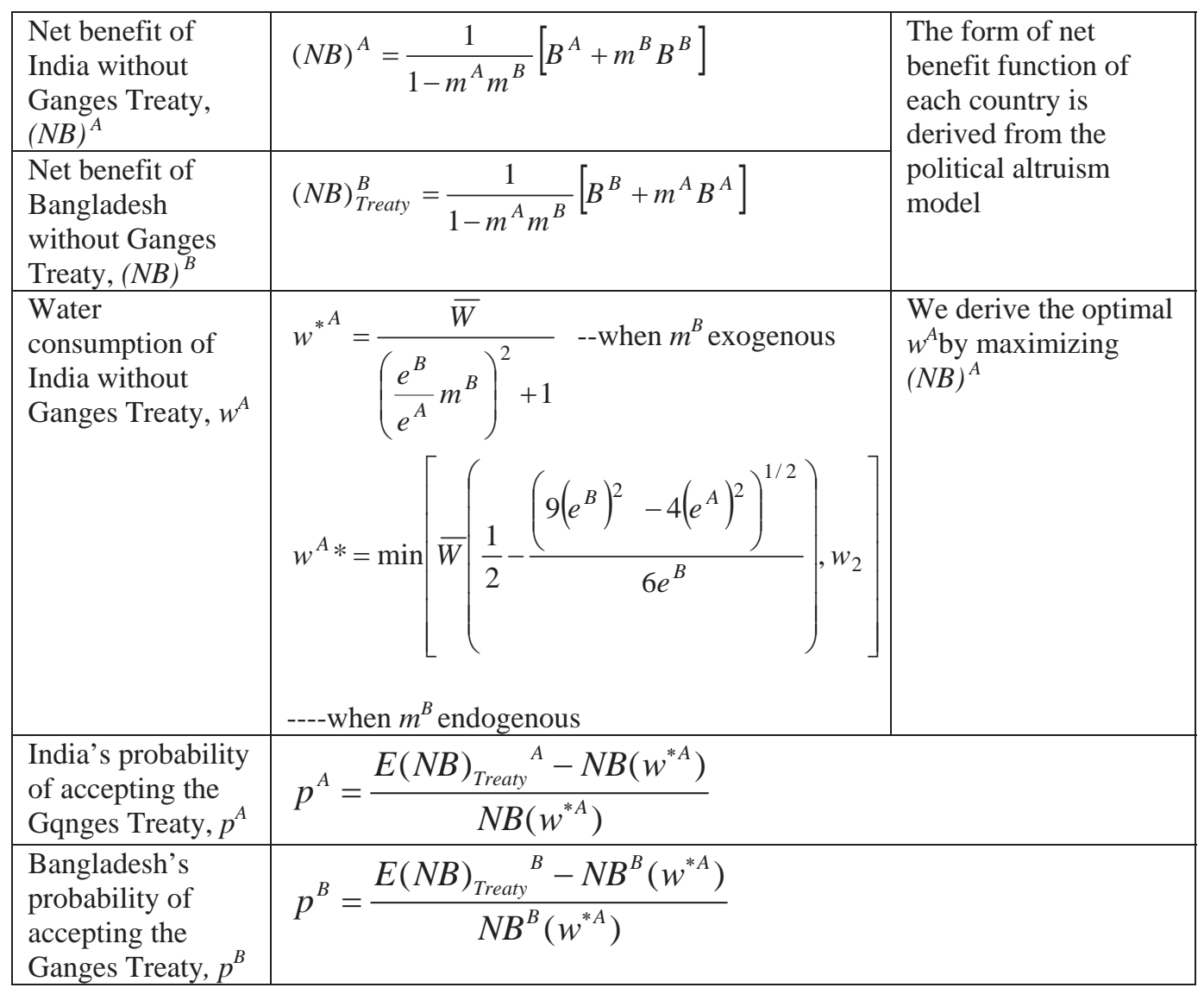

The key variable used in the simulation is the water flow of the Ganges River denoted by $W$. Using Best Fit Software and empirical data, we determine the distribution function of the water flow of the Ganges River. Simulation results suggest that the stochastic factor $\varepsilon_{t}$ is best fitted with a lognormal distribution with zero mean and a known constant variance $\sigma$, where $\sigma=13,790$. The long run average flow of water of the Ganges River is computed to be 77,413 cusecs. The simulations of $E\left(N B^{A}\right)$ and $E\left(N B^{B}\right)$ were conducted in both cases, with and without the Ganges Treaty. This in turn allows us to evaluate the probability of each country accepting the Ganges Treaty based on the potential gain from the treaty ( $p^{A}$ and $p^{B}$ respectively).

Figure 3 illustrates the results of the simulation and explains the relationship between India's probability of accepting the Ganges Treaty and Bangladesh's political relationship with India. In contrast to the inverted Ushaped relationship between India's probability of agreeing to the Ganges Treaty $p^{A}$ and altruism $m^{B}$, the simulation results of Figure 3 show a positive relationship between $p^{A}$ and $m^{B}$. India's initial endowment of water was high 
when the Ganges Treaty was signed, and India would therefore have a lower marginal benefit for water and would also be relatively less risk averse than Bangladesh. This may have motivated India to accept the Treaty with higher probability for an increase in $m^{B}$. It appears the endowment effect is greatly outweighed by the altruism effect in our simulations. ${ }^{20}$

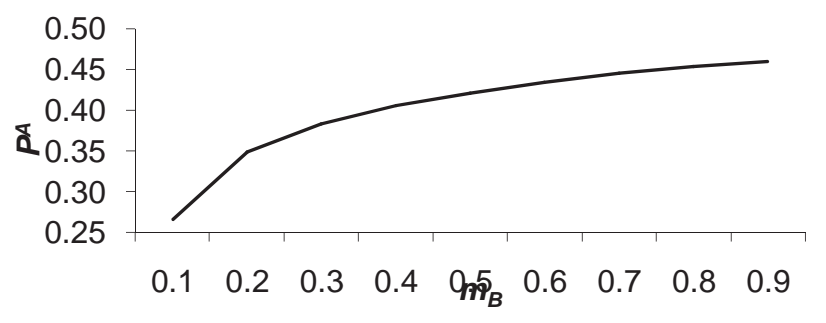

Figure 3: Simulated probability of India's accepting the Ganges Treaty as a function of Bangladesh's political relationship

In similar fashion, we have computed Bangladesh's probability of agreeing to the treaty.

Table 2 shows the simulation results of Bangladesh's probabilities of agreeing to the Treaty, shown in unbolded type, in the case with equal efficiency of water in two countries. The table also illustrates the simulation of the probabilities of India accepting the Ganges Treaty, represented in the table as bold numbers. Both the country's chances of accepting the water sharing treaty will vary with different values of $m^{A}$ and $m^{B}$.

Table 2: The probabilities of accepting the Ganges Treaty; exogenous $m^{B}$; $\boldsymbol{e}^{A}=\boldsymbol{e}^{\boldsymbol{B}}$ (bold-India; not bold-Bangladesh).

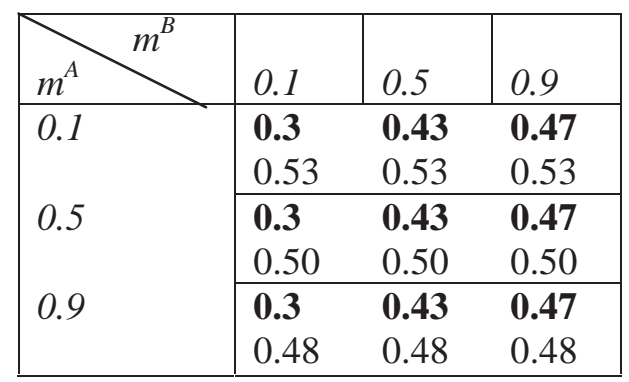

\footnotetext{
20 Note that in Figure 3, there exists a kink. India's probability of agreeing to the Treaty will increase linearly before the kink, but increases at a decreasing rate afterward. The existence of the kink can be justified by the assumption of constrained capacity of water diversion in India.
} 
Simulation results in Table 2 suggests that Bangladesh's probability of agreeing to the Treaty (unbold numbers) will be higher than that of India (bold numbers) for all values of $m^{A}$ and $m^{B}$. Bangladesh's probabilities are higher as the latter country receives less water without the Treaty and the endowment affect dominates the altruism effect and induces Bangladesh to accept the treaty with higher probability. The higher probabilities can also be attributed to higher uncertainty of water flow and difference in information about water flow. With increase in $m^{A}$, Bangladesh claims less water and its probability of accepting the treaty decreases.

As shown in Table 2, India's probability would increase with $m^{B}$ as altruism is the main motivating force behind accepting the Treaty. India's probability of accepting the Treaty would remain the same with an increase in $m^{A}$. The results indicate there are higher probabilities for the countries to accept the treaty with low $m^{A}$ and high $m^{B}$. Our simulation result in Table 2 indicates that to induce India to accept the Ganges Treaty, Bangladesh might have maintained a good political relationship with India. Conversely, India might not have needed to maintain as good a relationship with Bangladesh to have the Treaty accepted. Overall, it appears that it is more important that the downstream country pursues close ties with the upstream country than vice versa for a successful treaty. Intuitively this is appealing as the downstream country has much more to gain through good relations given the upstream country's ability to unilaterally change water shares. We also illustrate a case where Bangladesh's political relationship is dependent on the share of water diverted by India upstream, thus India's altruistic concern about Bangladesh depends on its share of water diversion. The endogeneity of Bangladesh's political relationship with India could have influenced the water sharing allocation and the political relationships of the countries necessary to accept the Ganges Treaty. We compare the probabilities of each country accepting the treaty under two different cases: $m^{B}$ is exogenous and endogenous. Table 3 presents the simulation results. The simulation results suggest that if Bangladesh's political relationship with India, $m^{B}$, is endogenous or dependent on the share of water diverted by India, then the latter country would prefer to share more water with Bangladesh as $\mathrm{m}^{B}$ positively affects India's net benefit function; and the probability of India agreeing to the Treaty, represented by bolded numbers in Table 3 , would be higher than the case when it is exogenous.

Again, if $m^{B}$ is endogenous, then Bangladesh would receive more water from India and will be less risk averse than India to accept the Treaty. As a result 
Bangladesh's probability of agreeing to the Treaty will increase with $m^{A} .^{21}$ Overall, if Bangladesh's political relationship with India, $m^{B}$, is dependent on the share of water diverted by India, Bangladesh's probability of agreeing to the Treaty, will increase with $m^{A}$ while India's probability remain unchanged.Hence, India would have to demonstrate a willingness for a better political relationship with Bangladesh to make the Ganges Treaty acceptable.

Table 3. The probabilities of accepting the Ganges Treaty (bold-India; not bold-Bangladesh)

\begin{tabular}{|l|l|l|}
\hline & $m^{B}$ & \\
$m^{A}$ & Exogenous & Endogenous \\
\hline 0.1 & $\mathbf{0 . 4 2}$ & $\mathbf{0 . 4 8}$ \\
\hline & 0.53 & 0.45 \\
\hline 0.5 & $\mathbf{0 . 4 2}$ & $\mathbf{0 . 4 8}$ \\
\hline & 0.51 & 0.47 \\
\hline 0.9 & $\mathbf{0 . 4 2}$ & $\mathbf{0 . 4 8}$ \\
\hline & 0.49 & 0.48 \\
\hline
\end{tabular}

It took a long time for both the countries to sign the Ganges Treaty. In the past, India and Bangladesh signed several treaties but none of them were successful. In 1977 India and Bangladesh signed an accord regarding water sharing, but the agreement was respected only for a short period when the latter country was under dictatorial rule. It took several years for both countries to consider renegotiating another treaty. When democracy was restored in Bangladesh in the mid 1990's, the governing parties in both countries desired to improve bilateral relations (Huda 2001). The fruits of a better relationship were reflected in the signing of the Ganges Treaty. The Ganges Treaty is now more than ten years old, and highlights how sustained democracy may lead to a stable policy regarding water sharing in the south East Asia.

Implementing democracy through an electoral process may not be the only reason for the delay in the successful outcome of water sharing of the Ganges River. It may have taken some time for the political parties to understand the distribution function of the electorate preferred policy and thus to devise an optimal equilibrium offer of policies. As the uncertainty about the electorate's preferences decreases, the political process in each country would eventually offer

${ }^{21}$ In a dynamic setting, one would imagine the dominant country generally being cooperative, but occasionally using short less cooperative policies to influence the electorate of the other country by reinforcing the importance of a good relationship. 
a set of policies, including those governing desired external relationships and altruism towards the other country which would not deviate far from the median view of the electorate.

There is good reason for believing that reducing the uncertainty over voters' preferences might take some time, especially in the case of the long history of negotiations over allocating water from the Ganges River. In the political altruism model, as explained in section 3, the altruistic concerns are determined from the distribution function of the electorates' preference at a point in time. The distribution function, however, can change over time in a systematic or a random manner. The electorates could update their beliefs and attitudes, which for example might have been conditioned on the failures of past negotiations over the Ganges River Treaty. Therefore, the electorate may have needed a longer time to find a cooperative treaty, because the past failures to reach a negotiated solution may have delayed any altruistic tendencies towards the other country. However, now that the Ganges River has been implemented successfully for ten years, the effectiveness of the treaty may enhance the reciprocal altruism motive in both India and Bangladesh. Overall, one might predict that in the future both the countries may sign a better treaty than the existing Ganges Treaty, addressing the issue of efficiency of water usage as the electorates preference continue to evolve toward closer ties with the other country.

\section{Conclusion}

With increasing demand relative to water scarcity, the allocation of water between two nations in a transboundary water sharing is inherently a "zero sum game" and intensifies the water conflict between the two nations. Current economic and planning literature assumes that such water conflicts can be resolved by analyzing the river basin as a single unit. In the absence of a "supra-national authority", however, the river basins shared by more than one country cannot be easily planned and developed cooperatively unless both the upstream and the downstream countries agree. In this paper, we have demonstrated that the altruistic concerns of the countries, dependent on the other country's willingness to have a good political relationship, can form the basis of water allocation with an objective to resolve water conflict.

We also have demonstrated in this paper using the political altruism model of water sharing, why India by signing the Ganges Treaty might have agreed to forego unilateral diversion of water upstream in order to cooperate with Bangladesh on water sharing of the Ganges River.

The results of the political altruism model seem plausible in light of the actual events in the early 1990s leading up to the signing of the Ganges River 
Treaty in 1996. A critical factor behind the successful negotiation of this treaty appears to have been the desire of the governing parties in both countries to improve bilateral relations. One of the key results suggests that with favorable political relations, both countries would have agreed to share water as determined by the Ganges Treaty. If Bangladesh's political relationship with India is independent of the share of water diverted by the latter country, then the willingness of Bangladesh to have closer relations was critical for a successful negotiation of the Ganges Treaty. If we consider Bangladesh's political relationship with India to be dependent on the share of water diverted by India, then the probability of India agreeing to the Treaty would have been higher than in the independent case. These observations all appear to be borne out in the historic record. The Ganges Treaty was signed in the context of a thaw in political relations between countries and an effort to improve political ties motivated by the preferences of the electorates in both nations.

\section{Appendix}

\section{Figure A1: Map of the Ganges River Basin}

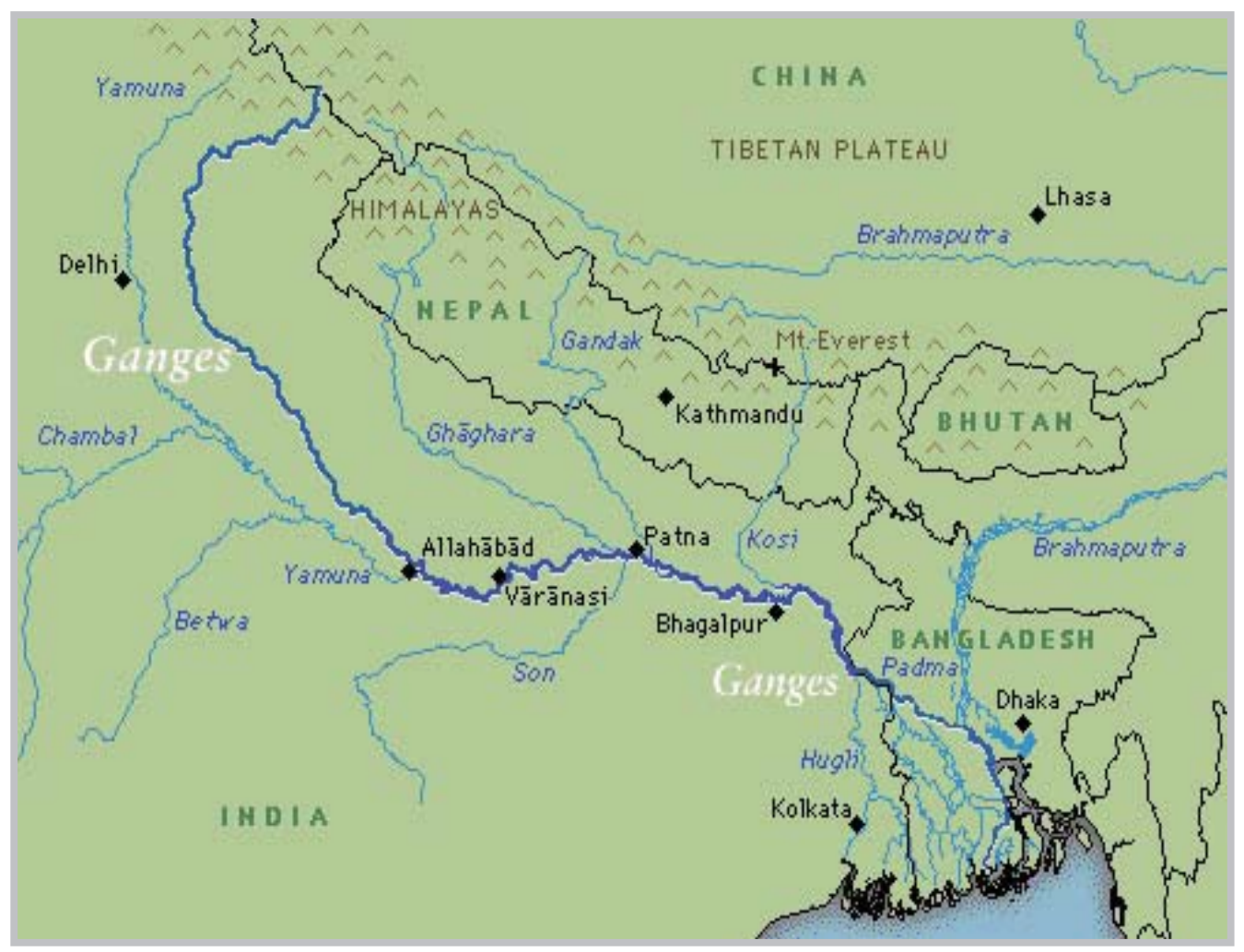


The B.E. Journal of Economic Analysis \& Policy, Vol. 8 [2008], Iss. 1 (Topics), Art. 32

\section{References}

Alam Z Undala. 1998. "Water rationality: Mediating the Indus Waters Treaty." Thesis submitted for the degree of Doctor of Philosophy, Geography Department, University of Durham, September 1998.

Andreoni, J. 1989. "Giving with Impure Altruism: Applications to Charity and Ricardian Equivalence.” Journal of Political Economy 97:1447-1458.

Arrow, Kenneth J. 1951. Social Choice and Individual Values. Wiley, New York. 2nd ed., 1963.

Becker. G.S. 1974. "A theory of social interactions." Journal of Political Economy 82:1063-1093.

Bennett, Lynne L., Shannon E. Ragland and Peter Yolles. 1998. "Facilitating International Agreements Through an Interconnected Game Approach: The Case of River Basins." In Richard E. Just and Sinaia Netanyahu, eds., Conflict and Cooperation on Transboundary Water Resources. Kluwer Academic Publishers, Boston, pp. 61-85.

Bergstrom, T.C. 1989. "Love and spaghetti: The opportunity cost of virtue." Journal of Economic Perspectives 3:165-173.

Black, Duncan. 1948. "On the Rationale of Group Decision-making." Journal of Political Economy 56:23-34.

Bramoullé, Yann. 2001."Interdependent Utilities, Preference Indeterminacy, and Social Networks." Department of Agricultural and Resource Economics, University of Maryland, College Park, MD.

Chelius, James R. and James B Dworkin. 1980. "An Economic Analysis of Final Offer Arbitration as a Conflict Resolution Device." Journal of Conflict Resolution 24:293-310.

Chiappori, P. 1988. "Rational Household Labor Supply." Econometrica 56:6389.

Coase, R.H. 1960. "The Problem of Social Cost.” Journal of Law and Economics $3: 1-44$.

Colomer, Josep M. 2000. "The Median Voter Maximizes Satisfaction and Minimizes Polarization: Worldwide evidence since the $19^{\text {th }}$ century." Higher Council of Scientific Research (CSIC) and University Pompeu Fabra (UPF), Barcelona.

Congleton, Roger. 2002. "The Median Voter Model." In C. K. Rowley and F. Schneider, eds., 2003. The Encyclopedia of Public Choice. Kluwer Academic Press.

Crow, Ben, Alan Lindquist and David Wilson. 1995. Sharing the Ganges. University Press Ltd, Dhaka.

Dinar, Shlomi and Ariel Dinar. 2000. "Negotiating in International Watercourses: Diplomacy, Conflict and Cooperation." International Negotiation 5:193-200. 
Bhaduri and Barbier: Political Altruism of Transboundary Water Sharing

Downs, A. 1957. An Economic Theory of Democracy. Harper Collins, New York: Dutta, J., and P. Michel. 1998. "The Distribution of Wealth with Imperfect Altruism." Journal of Economic Theory 82:379-404.

Dutt, Pushan and Ahmed Mushfiq Mobarak. 2007. "Democracy and Policy Stability." INSEAD Business School Research Paper No. 2007/50/EPS, Singapore.

Dworkin, James B. and Angelio S. DeNisi. 1981. "Final Offer Arbitration and The Naive Negotiator." Industrial and Labor Relations Review 35:78-87.

Esteban, Joan, and Debraj Ray. 1999. "Conflict and Distribution." Journal of Economic Theory 87:379-415.

FAO. 1996. "Food Production: The Critical Role of Water." World Food Summit, Rome, Food and Agriculture Organization of the United Nations

Farber, H. 1980. "An Analysis of Final-Offer Arbitration." Journal of Conflict Resolution 35:683-705.

Goodin, Robert E. 2005. Reflective Democracy. Oxford University Press, New York .

Hori, H. 1992. "Utility Functionals with Nonpaternalistic Intergenerational Altruism:The Case Where Altruism Extends to Many Generations." Journal of Economic Theory 56:451-467.

Hossain, Ishtiaq. 1998. "Bangladesh-India Relationship: The Ganges WaterSharing Treaty and Beyond." An American Review 25(3):131-151.

Hotelling, H. 1929. "Stability in competition." Economic Journal 39:41-57.

Huda, A.T.M. Shamsul. 2001. "Constraints and Opportunities for Cooperation Towards Development of Water Resources in the Ganges Basin." In Asit K. Biswas and Juha I. Uitto, eds. Sustainable Development of the GangesBrahmaputra-Meghna Basins. United Nations University Press, New York pp. 46-57.

Johansson-Stenman, Olof. 2002. Global Environmental Problems, Efficiency and Limited Altruism. Department of Economics, Göteborg University, Sweden.

Kimball, M.1987. "Making Sense of Two-Sided Altruism." Journal of Monetary Economics 20:301-326.

Kolm S.C. 2000. “The Logic of Good Social Relations.” Annals of Public-and Cooperative Economics 71(2):171-89.

LeMarquand David G. 1977. International Rivers: The Politics of Cooperation. University of British Columbia and the Waterloo Research Centre.

McKelvey, Richard. 1976. "Intransitivity in Multidimensional Voting Models and Some Implications for Agenda Control." Journal of Economic Theory 12:47282.

Plott, Charles. 1967. "A Notion of Equilibrium and its Possibility under Majority Rule." American Economic Review 57:787-806. 
Powell, Jr., G. Bingham. 2000. Elections as Instruments of Democracy: Majoritarian and Proportional Visions. Yale University Pres, New Haven.

UNESCO. 2001. "World Water Development Report Facts and Figures." United Nation, New York.

Verghese B.G. 1997. "Water Conflicts in South Asia." Studies in Conflict \& Terrorism 20:185-194.

Verghese B.G. 1999. "Waters of Hope." Oxford and IBH Publishing Co, New Delhi.

Verghese B.G. 2001. "From Dispute to Dialogue to Doing." Ch. 9 in Asit K. Biswas and Juha I. Uitto, eds. Sustainable Development of the GangesBrahmaputr-Meghna Basins United Nations University Press, Tokyo, pp. 163-189.

Cosgrove, William J. and Frank R. Rijsberman. 2000. World Water Vision: Making Water Everybody's Business. World Water Council and Earthscan Publications, London.

Wolfe, Aaron T, Shira B. Yoffe and Mark Giordano. 2003. "International Waters: Identifying Basins at Risk.” Water Policy 5:29-60. 